Nevada

Environmental

Restoration

Project
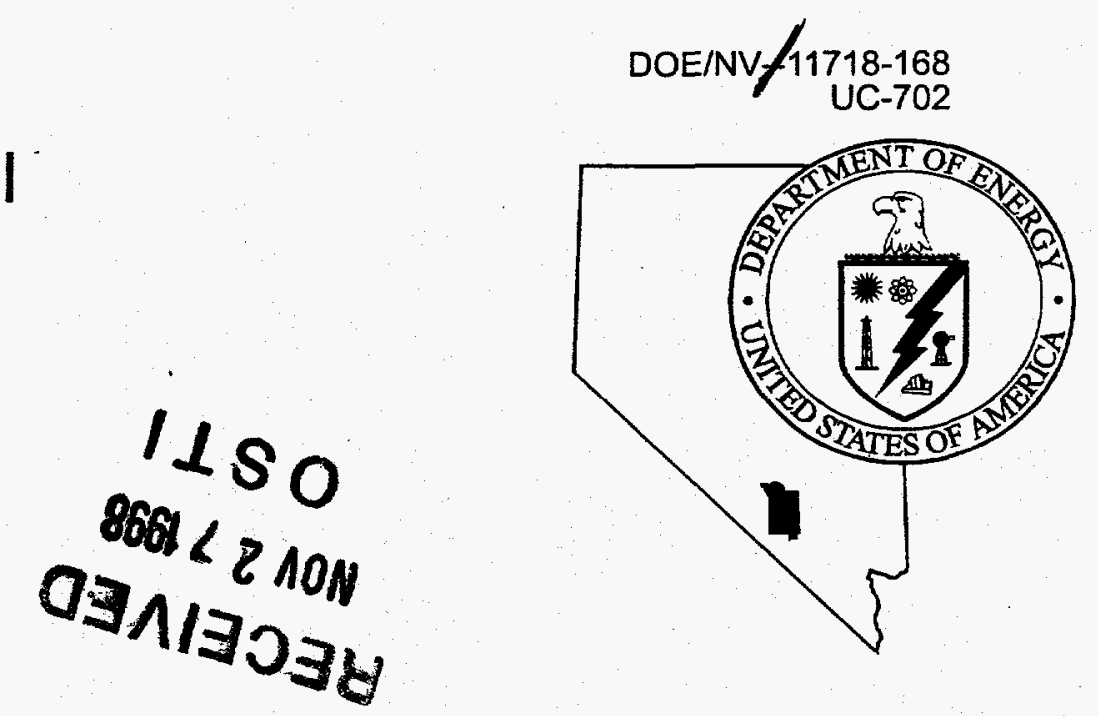

Closure Report

for Housekeeping Category

Corrective Action Unit 353

Nevada Test Site

\title{
UNCONTROR:ED COPY
}

Controlled Copy No.

Revision: 0

January 1998

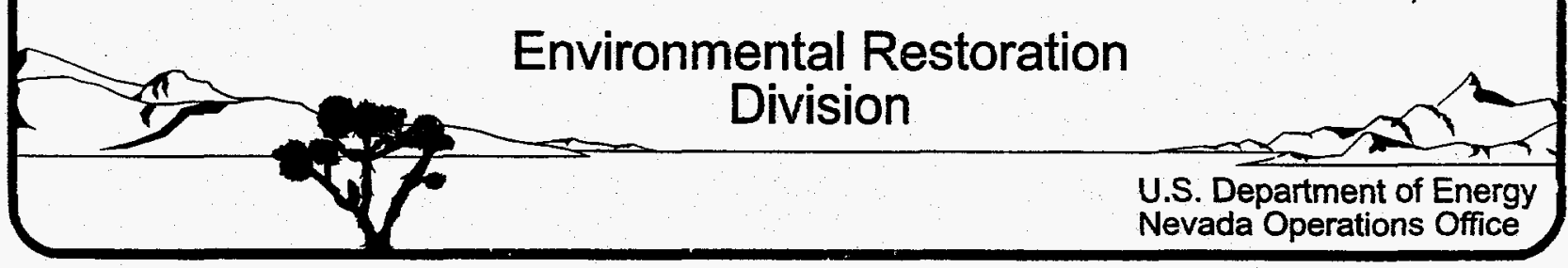




\title{
CLOSURE REPORT FOR HOUSEKEEPING CATEGORY CORRECTIVE ACTION UNIT 353 NEVADA TEST SITE
}

\author{
Prepared for \\ U.S. Department of Energy \\ Nevada Operations Office \\ Under Contract No. DE-AC08-96NV11718

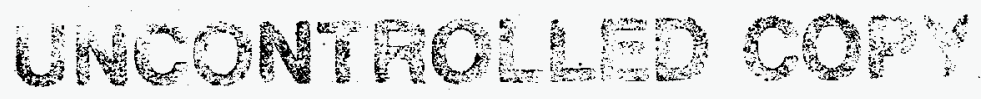

Controlled Copy No.:

Revision: 0

DISTRIBUTION OF THIS DOCUMENT IS UNM MIED

Prepared by

Bechtel Nevada

Environmental Restoration

MASTER

January 1998 


\section{DISCLAMMER}

This report was prepared as an account of work sponsored by an agency of the United States Goverament. Neither the United States Goverameat dor any agency thereof, nor any of their employees, makes any warranty, express or implied. or assumes any legal liability or responsibility for the accuracy, completeress. or use. fulbess of any information, apparatus, product, or process disciosed. or represents that its use would not infringe privately owned rights. Refereace berein to any specific commercial product, process, or service by trade name, tradernart, tananuac. turer, or otherwise does not necesenvily constimte or imply its endorsenent, recommendation, or favoring by the United States Government or any afency thereof. The views and opinions of authors expressed berein do not secssarily sute or rellect those of the. United States Governmeat or any agency thereof. 


\section{DISCLAIMER}

Portions of this document may be illegible in electronic image products. Images are produced from the best available original document. 


\section{FFACO HOUSEKEEPING CATEGORY CORRECTIVE ACTION UNIT 353}

\begin{tabular}{|c|l|l|l|}
\hline \hline $22-22-01$ & (7) Buckets & $\begin{array}{l}\text { The items were retrieved along } \\
\text { with other debris and disposed. } \\
\text { No further action required. }\end{array}$ \\
\hline $22-99-02$ & Water Fill & $\begin{array}{l}\text { The inactive water shed was } \\
\text { filled with native soil and the } \\
\text { metal cover was disposed. No } \\
\text { further action required. }\end{array}$ \\
\hline $22-99-03$ & Ammunition Storage Area & $\begin{array}{l}\text { Used by Camp Desert Rock } \\
\text { soldiers, only metal debris and } \\
\text { fencing materials remained for } \\
\text { disposal. Additional materials } \\
\text { cleaned from the area, } \\
\text { consisting of vehicle parts and } \\
\text { debris, included 22-19-02, 22- } \\
\text { 99-04, and 22-99-05. No further } \\
\text { action required. }\end{array}$ \\
\hline
\end{tabular}




\section{FFACO CORRECTIVE ACTION SITE HOUSEKEEPING CLOSURE VERIFICATION FORM}

Closure Verification Date: $\quad 09$-AUG-97

CAS Number: 22-22-01

CAU Number: 353

General Location: Weather Station

Elevation:

Latitude:

Northing: $682,657.144$

Longitude:

Easting: $691,164.332$

Coordinate/Elevation Data Obtained from Garmen 40 Global Position System: Accuracy is within $300 \mathrm{ft}$ Horizontal - Vertical Varies with Locality

Site Access Route: Mercury Hwy south through Gate 100, proceeding to Desert Rock Airstrip Rd. Turn right (west) and proceed $0.5 \mathrm{mi}$ access road, turn left (south) and go approx. $0.1 \mathrm{mi}$ to end of pavement. The CAS is 50 feet south of end of pavement (approx. $250 \mathrm{yds}$ east ff Air Resources Laboratory [Weather Station]).

\begin{tabular}{|l|l|}
\hline \multicolumn{1}{|c|}{ Waste Item(s) Originally at Site } & \multicolumn{1}{c|}{ Apparent Waste Type* $^{*}$} \\
\hline Buckets (7) & Ordinary \\
\hline
\end{tabular}

- Ordinary, Scrap Metal, Ashestos, PCB, Salvageable, Hazardous, Radioactive, Mixed, Unknown, Other

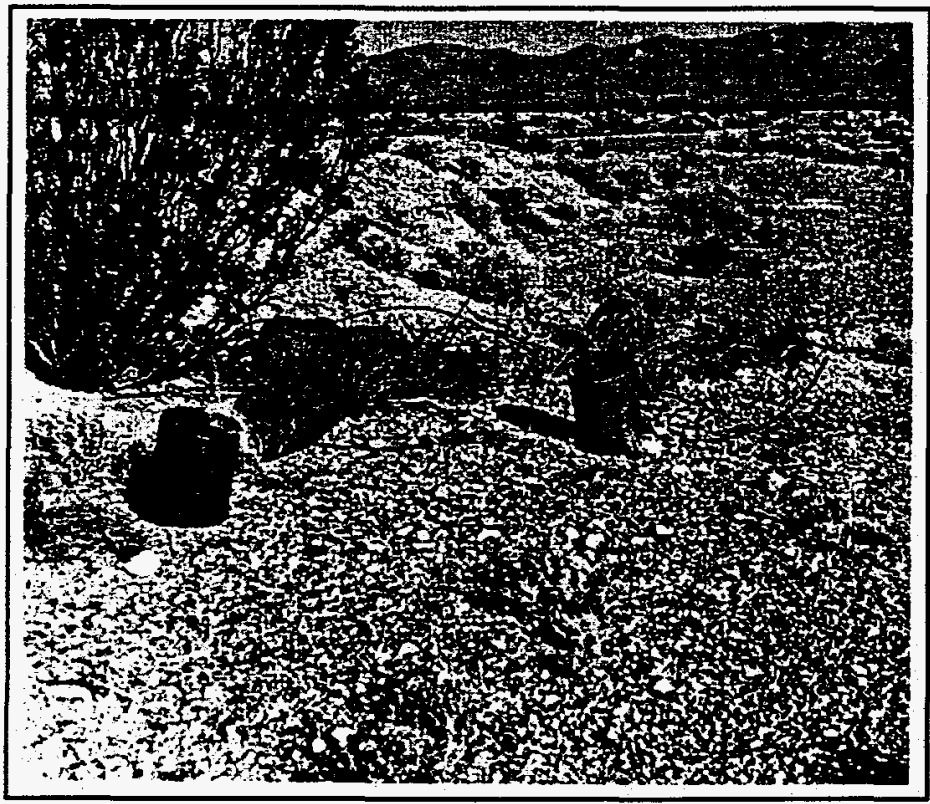

CAS Prior to Cleanup

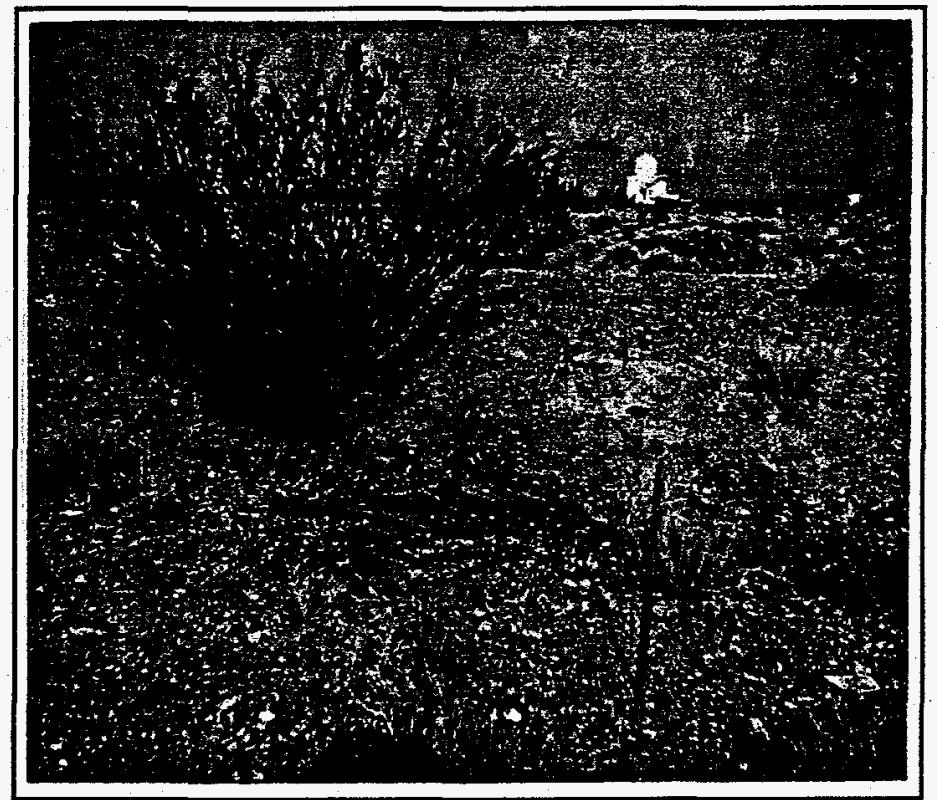

CAS After Cleanup

Current Site Description/Observations: Originally identified on 24-JAN-91, NTS personel retrieved seven empty 5-gal. metal buckets and steel cable segments on 09-AUG-97. This location is formerly known as a petroleum oil and lubricants dump and was active during the Camp Desert Rock encampment period (circa 1950s). No hydrocarbon-type staining was observed in the area. All solid waste was disposed at the Area 9 U10c Landfill.

No Further Action Required at Corrective Action Site

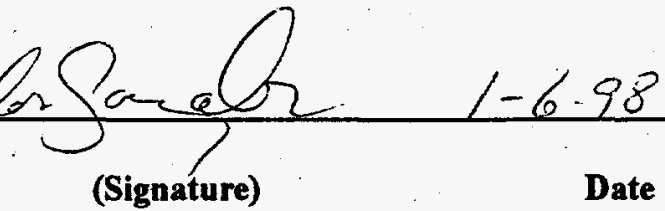




\section{FFACO CORRECTIVE ACTION SITE HOUSEKEEPING CLOSURE VERIFICATION FORM}

Closure Verification Date: $05-$ SEP-97

CAS Number: 22-99-02

General Location: Gate 100 (Power Pole \#44)

CAU Number: 353

Latitude:

Elevation:

Longitude:

Northing: $686,420.327$

Easting: $694,065.769$

Coordinate/Elevation Data Obtained from Garmen 40 Global Position System: Accuracy is within 300 ft Horizontal - Vertical Varies with Locality

Site Access Route: Mercury Hwy south through Gate 100, proceeding approximately $0.85 \mathrm{mi}$ to power pole \#44. CAS is on right (west) side of Mercury Hwy, approx. 104 feet from road, due west of power pole.

\begin{tabular}{|l|l|}
\hline \multicolumn{1}{|c|}{ Waste Item(s) Originally at Site } & \multicolumn{1}{c|}{ Apparent Waste Type $^{\star}$} \\
\hline Water Fill & Ordinary \\
\hline
\end{tabular}

* Ordinary, Scrap Metal, Asbestos, PCB, Salvageable, Hazardous, Radioactive, Mixed, Unknown, Other

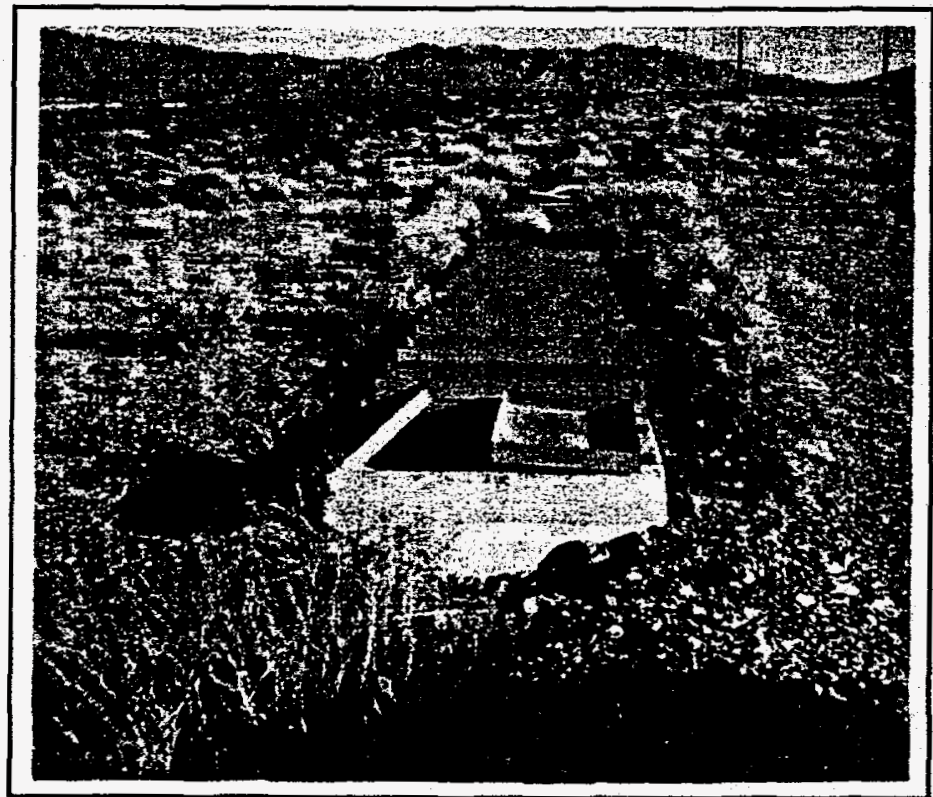

CAS Prior to Cleanup

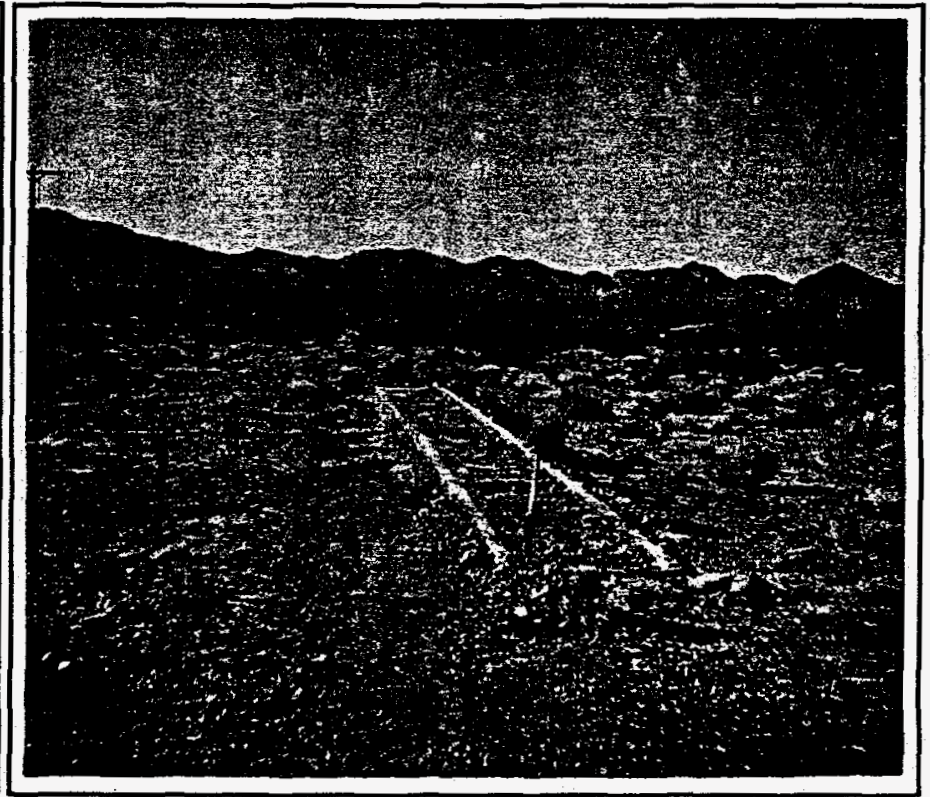

CAS After Cleanup

Current Site Description/Observations: Originally identified on 24-JAN-91, NTS field crews verified its location on 05-AUG-93. Per conversations with the NTS Water Department, this water shed was used in the early 1950s, but has been inactive ever since. NTS personnel removed the sheet metal cover for disposal at the A-23 Landfill and filled the cement trough with native desert soil. A marker at the northeast corner of the trough identifies the CAS.

No Further Action Required at Corrective Action Site

C. Carlos Gonzales 


\section{FFACO CORRECTIVE ACTION SITE HOUSEKEEPING CLOSURE VERIFICATION FORM}

Closure Verification Date: $05-S E P-97$

\begin{tabular}{|c|c|c|}
\hline CAS Number: & $22-99-03$ & CAU Number: \\
\hline General Location: & ARL/Camp Desert Rock & Elevation: \\
\hline Latitude: & & Northing: \\
\hline Longitude: & & Easting: \\
\hline
\end{tabular}

Coordinate/Elevation Data Obtained from Garmen 40 Global Position System: Accuracy is within 300 ft Horizontal - Vertical Varies with Locality

Site Access Route: Mercury Hwy south through Gate 100, proceeding to Desert Rock Airstrip Rd. Turn right (west) and proceed to Air Resources Lab (Weather Station) on left (south) side of road. The CAS is located approx. 600 feet south of the weather station.

\begin{tabular}{|l|l|}
\hline \multicolumn{1}{|c|}{ Waste Item(s) Originally at Site } & \multicolumn{1}{c|}{ Apparent Waste Type* $^{*}$} \\
\hline Ammunition Storage Area (empty) & Ordinary \\
\hline
\end{tabular}

- Ordinary, Scrap Metal, Asbestos, PCB, Salvageable, Hazardous, Radloactive, Mixed, Unknown, Other

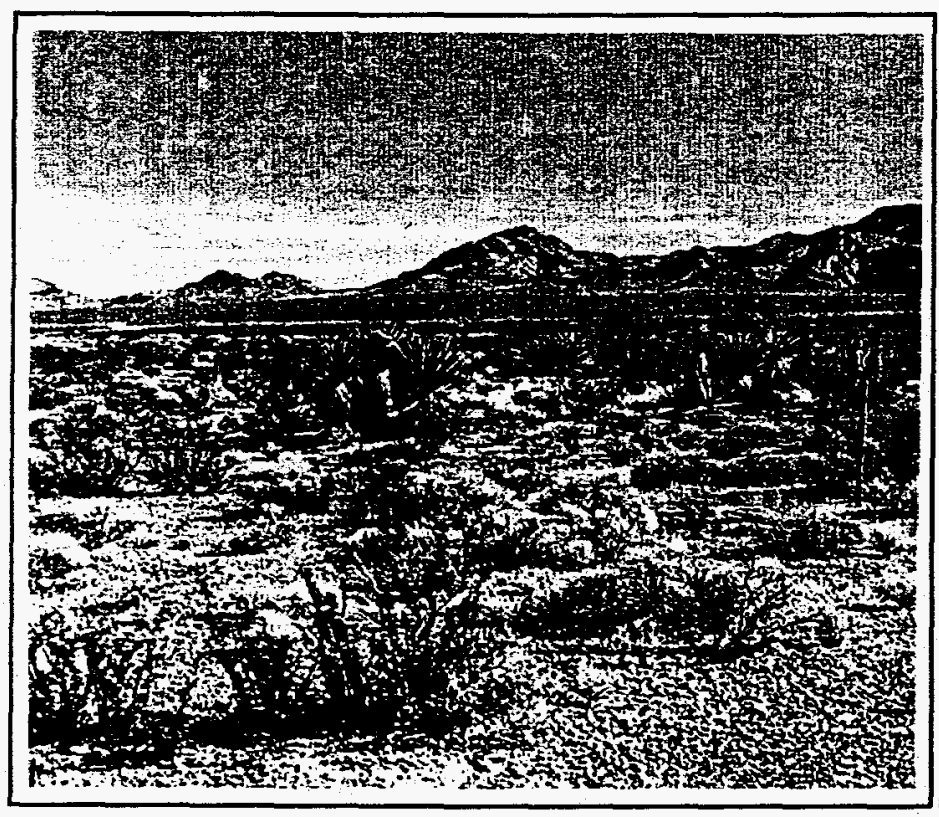

CAS Prior to Cleanup

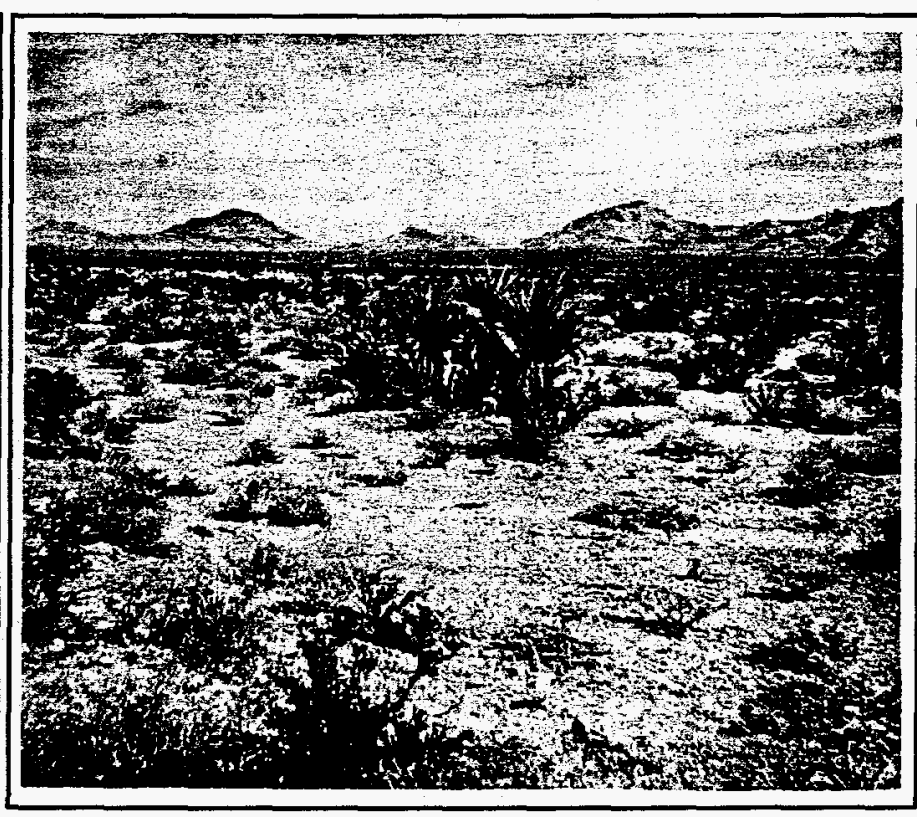

CAS After Cleanup

Current Site Description/Observations: Originally identified on 24-JAN-91, field crews verified its location on 26-SEP-95. Used by the military in the 1950s, only metal debris and fencing remained and were retrieved for disposal by NTS personnel. Three CASs which were in close vicinity were also cleaned: 22-99-04, consisting of metal debris and fencing; 22-99-05, military vehicle parts and metal debris; and 22-19-02, consisting of military vehicle parts and metal debris. An area surrounding AEC Well \#6 (10/9/51), SE of 22-99-03, was also cleaned of metal and glass debris. Markers identify each of the FFACO CASs.

No Further Action Required at Corrective Action Site

C. Carlos Gonzales

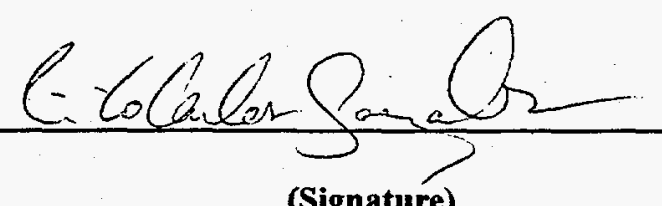
$1-6.88$ 


\section{DISTRIBUTION LIST}

U. S. Department of Energy, Nevada Operations Office

P. O. Box 98518

Copies

Las Vegas, NV 89193-8518

J. L. Appenzeller-Wing

Public Reading Room

Technical Information Resource Center

U. S. Department of Energy,

Office of Scientific and Technical Information

175 Oak Ridge Turnpike

P. O. Box 62

Oak Ridge, TN 37831

Bechtel Nevada

P. O. Box 98521

Las Vegas, NV 89193-8521

D. K. Cowser

J. R. Kannard

C. C. Gonzales

IT Corporation

4330 South Valley View, Suite 114

Las Vegas, NV 89103-4047

R. C. Silver 